\title{
EVOLUTION OF ENTREPRENEURS STATE SUPPORT SYSTEM IN THE NATIONAL ASPECT
}

\author{
Alena SHCHEMELEVA \\ Belarusian National Technical University \\ E-mail: Shchemeleva@yandex.ru \\ Daria DROZD \\ Academy of Public Administration \\ E-mail: dachamns@yandex.ru \\ doi:10.13165/IE-13-7-2-05
}

\begin{abstract}
The authors examine the national experience in the development of the system of entrepreneurs state support in the Republic of Belarus in a historical perspective (1992-2010), tracing the evolution of its forms and methods, leading to the reduction of government interference in the operation of market economic laws and, consequently, to the observance of the principles and rules of granting industrial subsidies, established by the World Trade Organization. The paper presents the results of the analysis of the scope, structure and dynamics of the state support to the Belarusian economy.
\end{abstract}

JEL classification: G18.

Keywords: state support, mechanism, volumes and objectives.

Reikšminiai žodžiai: valstybès parama, mechanizmas, apimtys ir tikslai.

\section{Introduction}

From the beginning of the 90s of the 20th century, intensive work has been in progress in Belarus on adapting the state-owned enterprises to the market business environment. While implementing the principle of the phased transition and minimization of negative effects of the given period, the adaptation of institutions to the market environment has been carried out, in particular, using the state support of entities, which carry out entrepreneurial activities [8].

In 1992, introduction of an institution of state support in the Republic of Belarus, granted in an individual order, was from the very beginning an anti-crisis measure, aimed at gradual reforming of economy without massive use of bankruptcy mechanisms, a method of maintaining social stability and preventing unemployment. It must be recognized that such measures are also employed by the governments of European countries, especially for the purposes of overcoming the consequences of financial crisis $[10,12]$. 
The role of the state in protecting the economic interests of society is growing all over the world. For this reason, the issues of form and efficiency of the state participation in the economy are a priority for the Republic of Belarus, too [2]. The rules of international trade are also of substantial significance for Belarus. The existing approaches to granting the state support in the Republic of Belarus for a number of criteria fail to meet the principles and guidelines of the state support for the economy by means of its subsidization, determined by the World Trade Organization (WTO). At the same time, the trade partners of the country are the WTO member countries or the countries that are getting ready to become the WTO members. In this connection, they follow the rules of the WTO and are oriented to following the rules by the countries importing the goods, as well. Simultaneously, a fairly common view should be noted that the mechanism for the allocation of financial resources by the government creates a dependency from entities that receive funds from the budget. It is generally recognized that the benefits, in particular tax payments, lead to a distortion of economic laws, inefficient allocation of resources. The exemption from tax of ones leads to the withholding taxes on the others, which increases tax burden. Both foreign and domestic researchers note the ambiguity of the impact of state support on the economy.

\section{Development of State Support System in Belarus}

While analyzing the formation and development of the mechanism of state support [11] to the business entities in the Republic of Belarus, a number of milestone stages can be conventionally highlighted.

Sharp decline in production and deterioration of financial standing of the enterprises of the republic at the initial stage of transitional economy determined the necessity for the state support to the entities. Since 1992, by the decision of the government of the Republic of Belarus, the entities have been granted reliefs and exemptions on almost all taxes, levies and duties, which were aimed at stabilizing the situation in the economy, promotion of investment, introduction of new technologies and export.

The overwhelming majority of the decisions and orders of the government on tax reliefs and exemptions related to the relief from value added tax, excise and customs duties payable on goods imported to the customs territory of the Republic of Belarus. About one-fifth of these decisions and orders provided a delay in debt repayments to the budget with the exemption on penalties and sanctions.

Loans and credits were allocated from the budget, allowances of interest rates on domestic bank credits were granted, government guarantees were provided on external borrowings. Under the conditions of absence of a legal framework regulating these processes, the state subsidization at the first stage (1992-1996) was carried out practically uncontrollably: the volume and the results of the state support granted were not controlled. As a result, by 1996, the state support reached such volume that constituted a real threat to the state budget implementation. The necessity of harmonization of the state support system was evident.

The second stage of the Belarusian state support system development took place in the period from 1997 to 2000. It was characterized by toughening of the procedure for granting tax exemptions and reliefs and the development of a mechanism of control over the volume and directions of state support usage. During that period, the legislation stipulated 
that the tax exemptions, reliefs and customs facilities were to be granted by the President of the Republic of Belarus, as well as in order approved by him, involving a rather complicated procedure for examination and co-ordination of organizations' applications. However, the control mechanism of volumes and use directions of the state support did not create the conditions for economic growth and production efficiency improvement. Alongside that, no significant limitation of the state support happened: there was an annual increase in the state support volumes (2.4\% of the republican revenue side of the budget in 1998, 2.7\% in 1999, $3.2 \%$ in 2000) and in the quantity of organizations, in which the support was provided [11]. The state support volumes, as before, were assessed when preparing reports on the implementation of a budget for the next financial year. In this period, the largest share (over $60 \%$ ), like before, was taken by the exemptions on value added tax, excise duties, customs duties and fees in the structure of the provided tax exemptions. Significant benefits were provided in particular to conversion enterprises and organizations of the defense industry, businesses and television industry machine tools, all legal entities, importing to the republic raw materials for bread and pasta, alcohol, beer, sugar cane, cotton, and various types of process equipment. Some large enterprises of strategic importance were granted exemption on almost all of the existing taxes for the long term (3-5 years). In addition to the tax reliefs, another phenomenon became more widespread. It was the practice of providing budget loans and loans with a permanent extension of the terms of their return, granting tariff preferences in interest rates of bank loans to the real sector of the economy at the cost of the budget, the provision and repayment of the government guarantees on enterprises foreign loans at the cost of the budget.

The third stage of the formation of the state support system (2001-2002) was characterized by the establishment of a number of limitations for granting individual tax exemptions, reliefs and customs facilities and significant toughening of procedures for granting the state support [6] as well as transfer of control over expenditure of budgetary funds to the President level. As a result, the state support volumes in the form of the individual tax exemptions, reliefs and customs facilities were reduced (from $3.2 \%$ of the revenue of the national budget in 2000 to $1.7 \%$ in 2001), but the claims of legal entities for such exemptions and reliefs were still of mass rather than of exceptional nature (more than $70 \%$ of all preferences granted in 2001 referred to the category of privileges related to the exemption from import customs duties).

The fourth stage of the state support system development (2003-2005) was characterized by the introduction of a ban on granting individual tax exemptions and reliefs (in 2003 privileges were abolished in respect of 77 enterprises), which allowed for the more advanced forms of the state support. Provision was made for allocation of financial aid to organizations from the budget in the form of subsidies and funds for capital financing. Limitations were imposed on granting budget loans and credits. Control over use of budget funds was strengthened in three directions: indices of financial and economic activities were specified for the recipients of the state support (26 indicators, while some of them were detailed); the officials were charged with the personal responsibility (both administrative and criminal) for the efficiency of its use; measures were taken on the adequate centralized accounting of the aid volumes granted [5]. However, the requirement to streamline and tighten the approaches to the state support provision has not lost its relevance. The volume of the government support in 2002 amounted to $4.0 \%$ of budget revenues, in $2003-8.9 \%$, in $2004-8.7 \%$, whereas in 2005 it dropped to $4.0 \%$. 
The fifth stage of the state support system development (2006-2012) proposed the integrated regulation of these issues [4], the effective use of budget funds through the establishment of common requirements for state aiding in all forms and at all levels. The types of the state support currently in use (altogether 11 types) are shown in Figure 1.

According to the classification of the forms of the state support [1] in the Republic of Belarus, most numerous are the fiscal mechanisms in the form of subsidies from the state budget or tax exemptions, reliefs (types of support 1, 2, 3, 5, 6, 7, 9). Budgetary loans and borrowings - type 8 - are the forms of credit extension, which would not have be given to a company in accordance with generally accepted lending standards. Indirect methods of the support include types $4,10,11$. The greatest ratio of aid is granted by the decisions of the President - up to $91.8 \%$ (2006) of the total amount of state preferences.

\section{Analysis of the System of State Support for the Belarusian Economy}

It should be noted that the system of state support of the Republic of Belarus was repeatedly criticized by both international organizations and Belarusian economists. The current system of aid to the enterprises of state sector is a distinctive feature of the state economic policy. However, it leads to occurrence of rather serious distortions in the entrepreneurial environment, evens out the incentives for inefficient enterprises to improve their performance, leads to formation of an unequal economic environment for different groups of enterprises and in general puts the private sector in a less advantageous position [9]. In order to examine the current trends in the state support system of the Republic of Belarus, the period from 2003 to 2010 was studied.

Figure 1. Types of state support in the Republic of Belarus

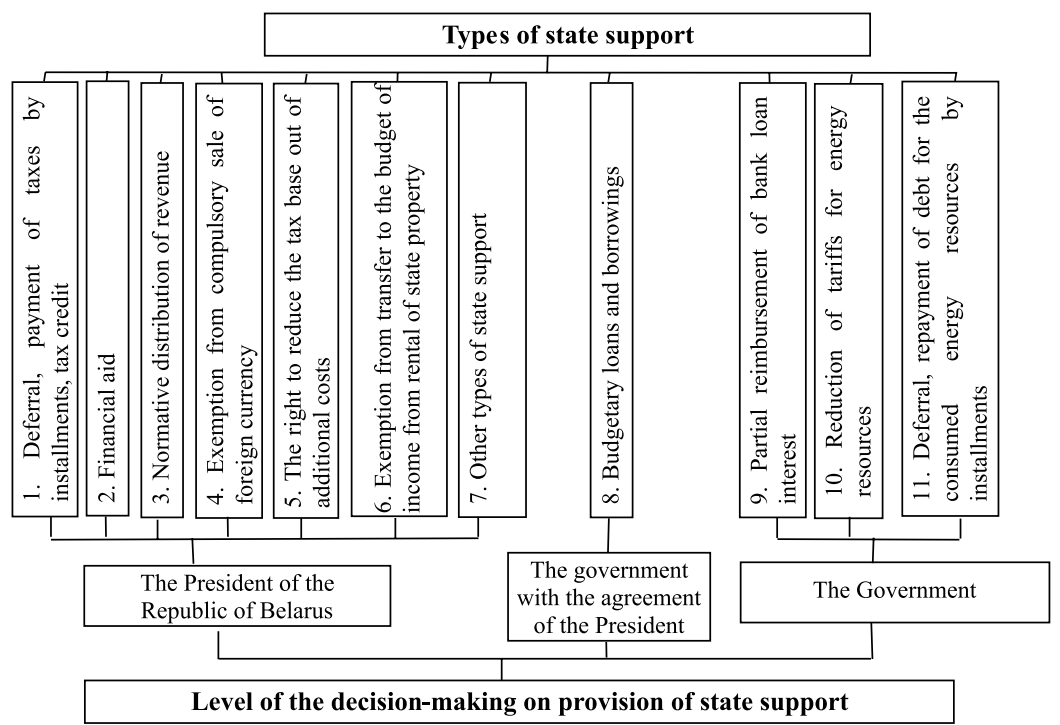

Source: developed by the authors (2013). 
The dynamics of state support volumes and the number of organizations that received it in the period from 2003 to 2010 is illustrated in Figure 2.

Figure 2. The scale of state support for enterprises

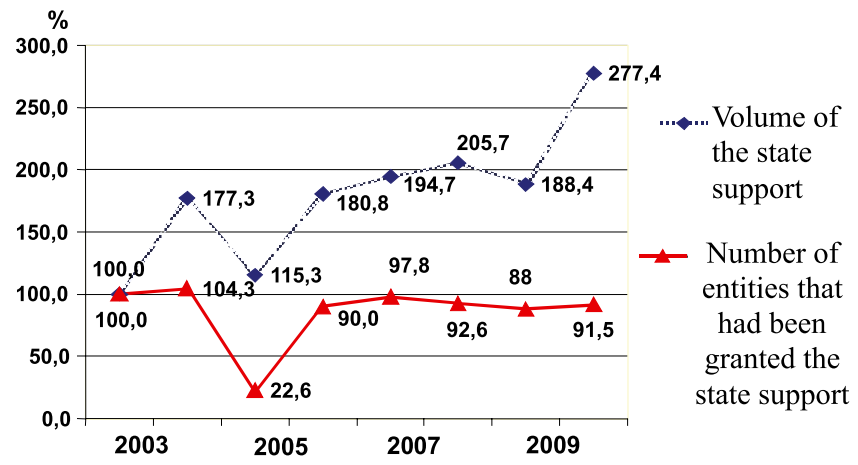

Note: the data of 2003 is taken as $100 \%$.

Source: developed by the authors (2012).

As it is seen in Figure 2, in the period under consideration there was a tendency towards the increase of state aid volumes. However, the number of entities granted the state support remained almost at the same level, which gives evidence of the increase of concentration of allocation of budgetary funds, i.e., "the state budget becomes the mechanism of systematic transfer of funds to the state sector of the economy" [3, p. 108].

Within the context of state support granting, the principle of its granting is of no little significance, which is shown in Figure 3.

Figure 3. State support granting on repayable terms and non-repayable terms

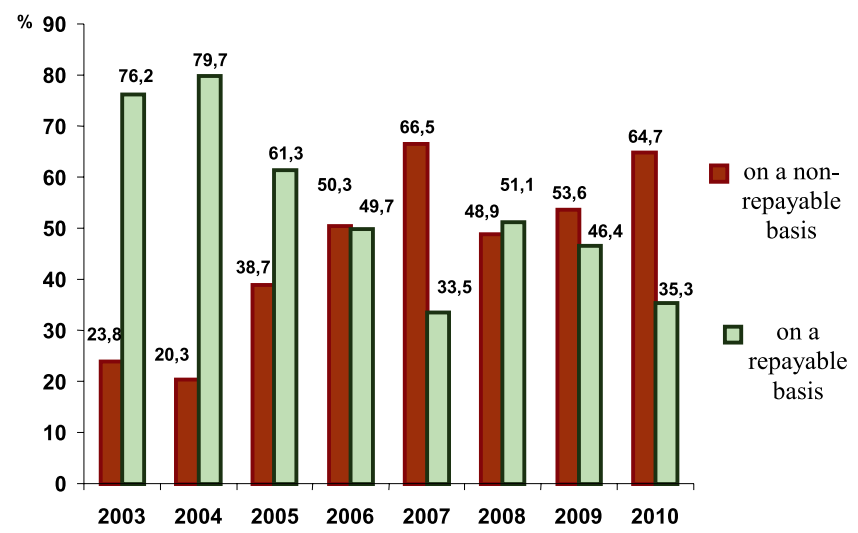

Source: developed by the authors (2012). 
As it is can be noticed in Figure 3, there was a tendency during the period under examination towards the decrease of proportion of the state support granted on a repayable basis (types 1,8 ) with a simultaneous increase of the state support volume granted on a non-repayable basis (types 2, 6, 9). It is evident that the state subsidizing on a repayable basis, including repayable and refundable, is more attractive for securing the fiscal function of the budget.

The objectives of granting state support are either improvement of financial standing of a company (mainly at the expense of narrowing the deficit of current assets), or carrying out investment measures (technical upgrading, modernization, reconstruction of production, mastery of novelties). Figure 4 presents the data on the dynamics of the structure of the state support, depending on the objectives of its granting.

Figure 4. Distribution of volumes of the state support depending on the objectives of its granting

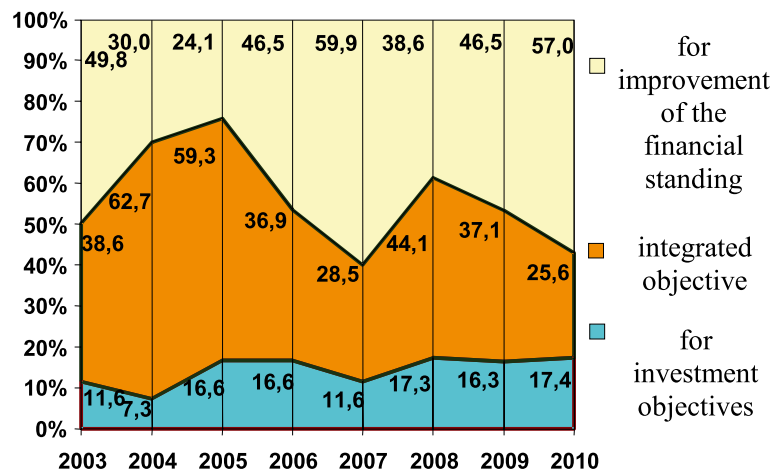

Source: developed by the authors (2012).

As it is shown in Figure 4, the tendency towards the increase of expenditures for the investment objectives practically is not observed, whilst the amount of aid granted with a view to improve the financial standing of the organization noticeably rises, which occurs at the expense of reduction of the state support granted for both of these objectives simultaneously (an integrated objective).

The results of the study of the volume and the state support subjects in the context of subordination of the organizations that received it in 2003 and 2010 are shown in the figure 5. 
Figure 5. The structure of the state support broken down by departmental affiliation of the entities that have received it

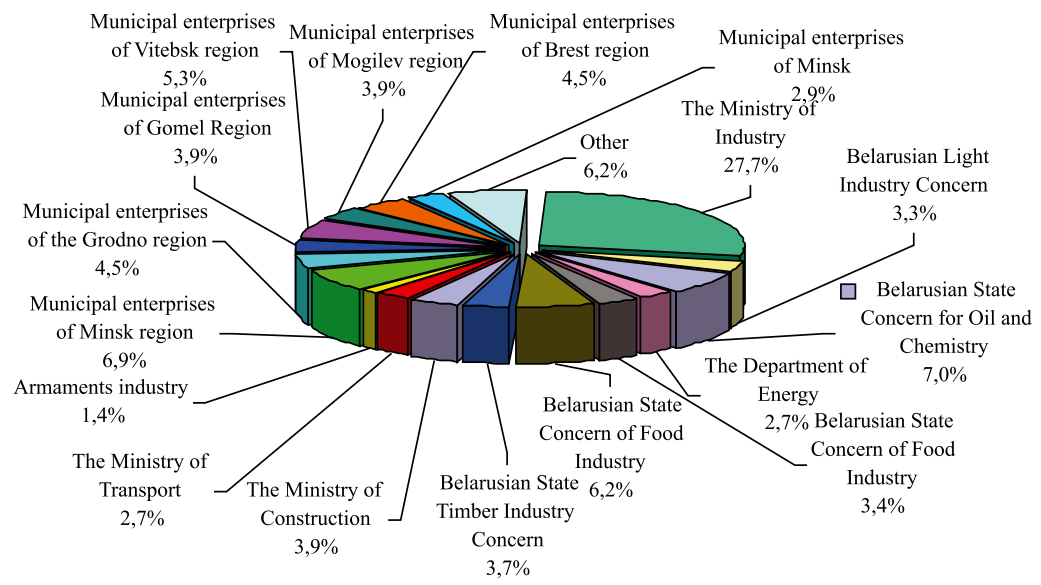

Note: average values of state support volumes for 2003-2010 are quoted.

Source: developed by the authors (2012).

As it is seen in Figure 5, during the studied period, enterprises of the Ministry of Industry, which accounted for a third of all amounts of state aid, remained the main recipients of the government support [7]. Such a distribution of the state support is caused by the sectorial and departmental structure of the real sector of the economy of the Republic of Belarus: the main potential of core enterprises is run by these structures.

The state support was granted based on a declarative principle. The condition for its granting was the achievement of certain indicator values of the profitability of sales growth in the output [13]. The structure of the state support by the number of organizations that had received it, depending on their fulfillment of the conditions for its granting for the period from 2006 to 2010, is shown in Figure 6.

Figure 6. Implementation of the recipients of the state support for the conditions of its provision

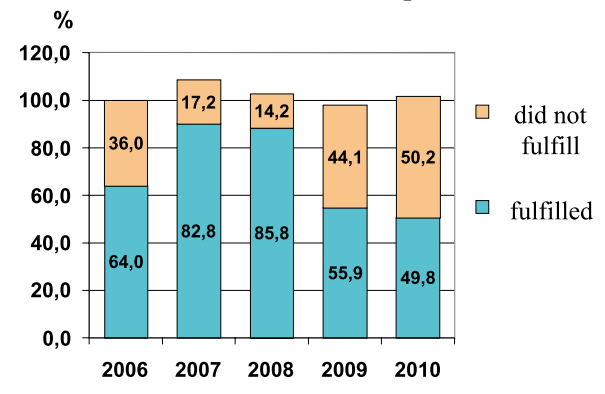

Note: the number of organizations in 2006 is taken as $100 \%$.

Source: developed by the authors (2012). 
As it is shown in Figure 6, whereas in 2006 36.0\% of organizations failed to fulfill the conditions for granting the state support, in 2010 this figure reached $50.2 \%$. Among the main reasons for the situation created are the declarative principle of granting aid without deep study of efficient causes of the necessity of its granting, low responsibility of certain managers, low competitiveness and structural changes in the assortment of the output product [2, p. 12-13], change in the external conditions for the supply of raw material and energy resources, high wearing of equipment and continuing processes of modernization of production, restraint of demand in the domestic and foreign markets with a relatively high level of tax burden, etc. In addition, there is also a rather significant problem of determining the efficiency of the state support by the extraction from the amount of the indices achieved of those values that are directly stipulated by granting state preferences. It is evident that the efficiency indices are influenced to a varying degree by the other external and internal with regard to the enterprise factors. Taking into account the above stated facts, the state support efficiency assessment continues to remain one of the challenging and little explored issues.

\section{Conclusions}

The existing system of state support in the Republic of Belarus to the economic entities has the following peculiarities and characteristics:

a) individual approach underlies the order of granting state support: selection of recipients is based on examination of applications of certain enterprises and organizations;

b) annual increase in the state aid volume is under way, as well as preservation of relatively unchanged number of entities to whom it is granted;

c) the majority of funds (from $62.3 \%$ to $91.8 \%$ ) is allocated based upon the decisions of the head of the state;

d) there is a tendency towards reduction of the share of state support, granted on a repayable basis, which is less attractive for the fiscal constituent of the budget than its granting on a non-repayable basis;

e) direct subsidies accounted from $39.9 \%$ to $75.9 \%$ in different years;

f) from $7.3 \%$ to $17.4 \%$ of volume of selective state support were allocated in different years for an innovative development of enterprises;

g) the main recipients of state support remained the enterprises of the Ministry of Industry and agricultural undertakings, which accounted for two-thirds and more of the total state aid volume.

The task of the enhancement of efficiency of selective state support and transfer of emphasis to the goals of the innovative development of the enterprises is of especial acuteness. 


\section{References}

1. Корнаи, Я. Осмысливая феномен мягких бюджетных ограничений / Я. Корнаи, Э. Маскин, Ж. Ролан // Вопросы экономики. - 2004. - № 11. - С. 7-33.

2. Мясникович, М. О государственной поддержке и конкурентоспособности предприятий / М. Мясникович // Наука и инновации. - 2007. - № 8. - С. 9-19.

3. Никитенко, П. Предпринимательство в белорусской институциональной модели / П. Никитенко, А. Лученок // Общество и экономика. - 2005. - № 9. C. $82-112$.

4. О совершенствовании правового регулирования порядка оказания государственной поддержки юридическим лицам и индивидуальным предпринимателям: Указ Президента Респ. Беларусь, 28 мар. 2006г., № 182 // Консультант Плюс: Беларусь. Технология 3000 [Электронный ресурс] / ООО «ЮрСпектр», Нац. центр правовой информ. Респ. Беларусь. - Минск, 2010.

5. Об утверждении Положения о едином государственном реестре юридических лиц и индивидуальных предпринимателей, получивших государственную поддержку: постановление Совета Министров Респ. Беларусь, 30 июля 2004 г., № 930 // Консультант Плюс: Беларусь. Технология 3000 [Электронный ресурс] / ООО «ЮрСпектр», Нац. центр правовой информ. Респ. Беларусь. - Минск, 2010.

6. Об упорядочении предоставления льгот по налогам и таможенным платежам: Декрет Президента Респ. Беларусь, 27 фев. 2001г., № 6 // Консультант Плюс: Беларусь. Технология 3000 [Электронный ресурс] / ООО «ЮрСпектр», Нац. центр правовой информ. Респ. Беларусь. - Минск, 2010.

7. Сведения о государственной поддержке, оказанной юридическим лицам за счет средств республиканского бюджета // Официальный сайт Министерства финансов Республики Беларусь. - [Электронный ресурс] - 2012. - Режим доступа: http://www.minfin.gov.by/rmenu/execution/gospodderjka/

8. Серегина, С.Ф. Роль государства в экономике. Синергетический подход / С.Ф. Серегина. - М.: Дело и Сервис, 2002. - 288 с.

9. The World Bank Mission on the Discussion of the Possible Loan Granting for the Development Purposes: Memorandum. Belarus, December 2-17, 2008. Minsk, 2009 , p. 48.

10. Chatel, K. Aide d'État et Delocalisation d'Entreprises dans l'Union Européenne Élargie, in: Chatel, K. and Kirch, P. Rev. d'Économie Financière. 2007 (90): 1-10.

11. Drozd, D.N. State Support of Economic Players Based on a Differentiated Approach, in Ph.D. The Academy of Public Administration under the Aegis of the President of the Republic of Belarus. 2012, p. 121.

12. Government is Urged to Introduce Wage Subsidies. Regeneration a. Renewal. 2009: 8.

13. Some Aspects Regarding Accounting for Government Grants, in: Monea, A. et al. Management Agricol. 2010 (12, 3): 1-6. 


\section{VALSTYBĖS PARAMOS ENTREPRENERIAMS RAIDA NACIONALINIU ASPEKTU}

Santrauka. Autoriai analizuoja nacionalinę entreprenerystès paramos sistemos raidą Baltarusijoje nuo 1992 iki 2010 m., apibrèždami formų ir metodų evoliuciją, atspindinčią valstybès intervencijos ị rinkos ekonomiką mažejimą bei Pasaulio prekybos organizacijos nustatytų pramonès subsidijavimo principų bei taisyklių laikymąsi. Straipsnyje pristatyti analizès rezultatai bei pateikta detali valstybès subsidijų privačiam verslui struktūros, mechanizmų, paramos apimčių ir jų plètros apžvalga Baltarusijoje.

Alena SHCHEMELEVA - Assoc. Prof. Dr., Department of Marketing, Faculty of Marketing, Management, Entrepreneurship of Belarusian National Technical University. Research fields: methodology of accounting, crisis management of companies, public administration.

Alena SHCHEMELEVA - Baltarusijos nacionalinio technikos universiteto Rinkodaros, verslumo ir vadybos fakulteto Rinkodaros katedros docentė, mokslų daktarè. Mokslinių tyrimų sritys: apskaitos metodologija, įmonių krizių valdymas, viešasis administravimas.

Daria DROZD - Academy of Public Administration.

Daria DROZD - Viešojo administravimo akademija. 